\title{
The Role of the External Factor at the Trend Towards Pluralism in the Third World
}

\author{
Asaad Tarash Abdel Reda \\ University of Baghdad, Baghdad, Iraq
}

\begin{abstract}
Democratic conversion represents the regression of authority ruling systems in all its forms and types to replace other systems in rule depending on real public choice, legitimate political institutions, and honest elections as means to exchange and reach power. Also, this conversion is considered a substitute for the individual rule and violation of law and constitution. Several countries have witnessed this experiment in the third world. Even, the 1980s period is taken to be an indicator of the third world influenced by the democratic wave which has helped some Arabic countries to adopt democratic rule systems and to put an end to the uniparty system.
\end{abstract}

Keywords: democracy, third world, political systems, pluralism

Despite of the internal factors which are considered more powerful and more influential in providing the conditions and requirements of pluralism and the democratic transformations, this does not diminish the importance of external factors. The outside partner shares the inside partner in media, education, and growth, as well as in the development or prevention of the democratic proposal. So the major foreign powers and the international powers are considered partners in the management of the present and in forming the future.

The external environment has imposed the multilateralism and democratization on the third world states, in spite of the absence or lack of substantive conditions for democratization in most third world states. This means that we are facing an external environment that tries to impose a form of governance that does not take into consideration the necessary conditions for this country or other country in addition to the possibility of success or failure of that.

Therefore, the influence of the third world countries on the international environment forced them to adopt pluralism for reasons that are probably beyond its control, so they initiated several political and economic reforms, either because of the need of political elites in the third world to stay in power, or for their need for economic support, which is often conditioned on changing their political and economic systems.

We are here to examine the encouraging externalities of pluralism and democratization, so the process of democratization will be a problem or a crisis for the third world countries as long as the governments and regimes of those countries find themselves going towards the application of a formula to a system of rule that is not genuinely ready to be applied.

Understanding and clarifying this picture requires us to study political pluralism in the third world countries by starting to define the concept of pluralism applied to these countries. Then we try to shed light on

Corresponding author: Asaad Tarash Abdel Reda, Ph.D., College of Political Science, University of Baghdad, Baghdad, Iraq; research fields: political systems and the third world. 
the role of the external factor in the emergence of the pluralistic experiment and its establishment and consolidation in the third world countries. We then turn to the role of the external factor in the return to pluralism or what is known as the second wave of pluralism in the third world countries.

\section{The First Section: Effect of External Factors in the Emergence of the Second Pluralism in the Third World Countries}

The external factors of the trend towards pluralism in the third world countries are the most important factors that influence effectively and clearly on the emergence of political parties and thus the trend towards pluralism. Therefore, we can point out some of them:

First: the collapse of one-party system in the Soviet Union and Eastern Europe after the third world achieved its independence in the 1960s; it faced great difficulties in rebuilding the nation. The most dangerous one was to build the national economy and achieve national unity. Many of these countries aspired to the Soviet model. Not only because it proved very effective, but also because it differs in its method and history from the Western colonial countries. The socialist experience in the Soviet Union was able to transfer tsarist Russia from the stage of feudalism and backwardness to the stage of industrial progress, which made it a superpower, on the one hand. On the other hand, the Soviet Union had no colonial adventures in the third world countries. On the contrary, it supported the liberation movements that emerged in the third world countries, as well as the role played by the Soviet Union in supporting the governments with threatened Marxist tendencies, which they considered their natural protector. These reasons gave rise to confidence between it and the newly independent African regimes that were looking for a strong international ally away from the Western bloc. This prompted the third world countries to adopt the one-party Soviet model as the only remedy for tribal divisions in their societies and as an effective means of building a strong economy.

But the political and economic transformations are witnessed by the socialist camp and the countries of Eastern Europe since the mid-1980s, and the most important of which are: the fall of the one-party system, the closed political system, and the pattern of the economy oriented in these countries with its adoption of market economy policies, pluralism, and forms of democracy liberalism at the political level. The Soviet experience no longer provides an alternative economic strategy for democratic capitalism and is no longer a source of political inspiration, which weakened its influence in the third world countries.

The third world states were convinced that the collapse of communist regimes in Eastern Europe meant that one model of democracy remained the liberal pluralist model. The existence of a Leninist Marxist model of democracy was the strongest argument against the non-universality of the Western model and thus the most important justification for the multiplicity of democratic models. An end to the Marxist-Leninist model of democracy has no longer supported the notion of pluralism, especially that "the people who overthrew this model were not satisfied with the Western model as an alternative". The eastern camp states took forms of liberal democracy, which contributed to enshrining the legitimacy of democracy as a system of governance at the global level. The Western model was widely accepted in the third world in general and was consciously or unconsciously adopted by states, which found the Western model as the only savior capable of achieving national unity and economic development.

In other words, the third world countries found in the collapse of the Soviet Union and Eastern Europe and the failure of one-party system to win the ideas of pluralistic democracy and human rights advocated by the 
West as a result of the bad conditions of the third world societies and to seek to adopt these ideas, which would help them to avoid their problems without paying attention to the consequences.

After realizing that, there is no doubt that the one-party system is fundamentally disabled; it stands before its rise and progress because it

Imposes a unilateral ideology on its own. It seeks to mold the character of the individual according to the predetermined goal, in addition to establishing himself as a guardian of the people, determining for them what they think about and how they think. And one party teaches people to hide their preference behind hollow formulas that seem to reflect the will of the people.

Moreover, the experience proved firstly that the existence of one party does not mean a realistic concentration of power in the hands of the party only, but in the hands of the main person who is at the same time the head of power and the state. The party is directly linked to the personal power of the person of the leader and thus becomes a tool in the hands of someone rather than becomes a means to find strong institutions. Experience proved secondly the issue of life and its requirements in any society, whatever its nature is complex and intertwined, which makes it impossible for one party to have the absolute right to deal with these matters and requirements, because the control of one opinion is in danger of inertia and lack of creativity despite the intentions of the party and the efficiency of its leadership.

Second: the end of the Cold War. One of the reasons that explain political transformations and the adoption of party pluralism in the third world countries is that they no longer face the Cold War between two superpowers. Since the end of the Second World War, the United States and the Soviet Union have emerged as superpowers representing the poles of the international order. Their goal is to maximize their power and prevent other powers from trying to undermine it. The third world countries have become centers of international conflict between these two powers. And each of them dealt with these countries in the light of competing with the other without attention to the privacy of these countries. As a result of the Cold War, each camp was quick to provide assistance and protection to the political systems in these countries that it could support in the Cold War against the other camp, or to provoke unrest to any regime that stands in the way of the interests of the other camp regardless of the legitimacy and popularity of this system. The Cold War also resulted in the concealment of what is taking place within the third world countries. Both the socialist and the capitalist regimes have instigated misleading ideological propaganda about this or that system as democratic systems, although they are very authoritarian. This stage was the conquest of the peoples of the third world in favor of the rulers, and provided the presence of one of the two forces supporting for the elite holding the power. But once these elites are turned on by their American or Soviet friends, the military coups immediately come in the name of the people, democracy or national duty. The end of the Cold War, after the collapse of the socialist camp and the disintegration of the Soviet Union, resulted in a number of international changes that marked the demise of the international situation that prevailed during the post-World War II era and the emergence of an international situation that was based on new international foundations and concepts that expressed the will and policies of the dominant powers, which wanted to impose its democracy as a political system on all countries of the world, especially the third world, as "the most representative political system with the capitalist system that wants to guarantee its hegemony". The latter has a historic opportunity-in the words of former US President Richard Nixon - to reorganize the world to create a new global era that evokes the pursuit of democracy. 
After the demise of the communist threat and the disintegration of the Soviet Union, many regimes in the third world countries no longer enjoy the support of the United States, which is faster in revealing the reality of their dictatorial regimes, which was an opportunity that revealed the cover of the authoritarian and repressive practices of some of the rulers under the pretext of anti-communism and addressing the red tide which was harmful to national sovereignty and privacy. On the other hand, it has contributed to the creation of a conducive climate to the intervention of Western powers and the United States in the internal affairs of the states of the region under the pretext of fostering democracy and protecting human rights. These forces did not hesitate to invent pretexts and opportunities for authoritarian regimes to introduce democratic reforms, especially after the growing international criticism of those regimes, as happened with former President Marcos in the Philippines and former President Suharto in Indonesia. As in Zaire, that regime was associated with severe corruption and human rights violations.

Third: the third world countries; the idea of using economic support as a political weapon is not new, but in recent years, it has become a widely used strategic weapon that includes clear political and strategic concessions on the part of the recipient. This means expanding the use of this weapon for the purpose of imposing certain patterns of policies and trends and integrating recipient communities into a wide network of relationships and systems. It is also new that it is no longer used under the slogans of friendship and cooperation as it was in the past, but it has become the whole subject publicly and in the negotiations conducted by the media. It has also been used in one direction after the end of the international conflict between the two camps, particularly in the direction of serving the strategic objectives and interests of Western powers through human rights and democracy issues. Therefore, the assistances provided by the West to the third world countries have played a key and an important role in the transformations towards multilateralism witnessed by these countries. Such assistance is conditional on the need to adopt the capitalist model of economic and political pluralism.

As a result of the problems faced by the third world countries from civil wars and border conflicts between countries and the problems of famine and drought that have contributed to the delay of the development, it leads the third world countries to submit to the pressure of Western countries, which links food aid and the transition to multi-party and the link between this aid and democratic transformations is either in a hypocritical form or a punitive form. And by the threatening statements of Western officials or actually cutting off these aids, it raises more problems than raised by the aid, and gives credibility to these threats.

This trend has emerged in the United States, where it has linked its support to nations to achieve democratization and multi-partyism on the basis that these aids are limited to governments which apply democracy in the third world countries, where it gives high priority to provide new aid to the third world elections and strengthen the democratic means in governance.

In fact, many countries in the third world have been subjected to such pressure. Kenya has been subjected to internal and external pressures by Western countries to stop economic aid to Kenya after attempts to prevent the transition to multi-partyism in 1991. What Kenya had agreed was multi-party elections in 1991 and the holding of comprehensive presidential parliamentary elections at the end of 1992.

This Western pressure to impose a democratic transition has become so-called political conditionality of granting aid and loans. Donor countries have the right to define the conditions for providing assistance to developing countries that need assistance. It may be said that aid must be freed from conditions and provided to the needy countries voluntarily on the basis of moral obligation. But this argument does not achieve forcing to 
donor countries to abandon their conditions, and they believe their moral obligation must encourage the international community to respect human rights and practice democracy, which is in the interest of the third world countries to help them achieve development, because real economic and social development cannot be provided without democracy in today's world. Some viewed this aid as a new kind of imperialist hegemony over the people of the third world. What the West is trying to impose on the democratic transformations of the countries of the region goes far beyond the desire to spread the Western democratic model of governance to a serious effort to create a stable climate, economically appropriate to the network of vital and extensive interests it sponsors in this region. This was expressed by the US ambassador to Indonesia, Huhtala, by saying that the democratic changes taking place in Indonesia, the third largest democracy in the world, represent an important opportunity for American interests. These interests, for example, are represented by 300 American companies investing about $\$ 750$ million in Indonesia and about 3,500 jobs for Americans in Indonesia alone.

However, it can be said that the use of aid weapons by Western countries was a good means of democratization in the third world countries.

\section{The Second Section: Democracy in the New International Situation}

The international situation at each of its stage was based on certain foundations and concepts. The new international situation that began after the collapse of communist regimes and the end of the Cold War as well as the United States' unilateralization of the new system was based on the new principles of advocating to democracy. It caused a wave of global transformation during the last quarter of the 20th century. Democratization or democratization processes represented the most important global phenomenon during the last decades of the 20th century.

Since the mid-1970s, the world has witnessed what has become known as the third wave of democracy, which began in Portugal, Spain, and Greece since 1974, then spread to Latin America and parts of Asia during the 1980s and extended to Eastern Europe, the Soviet Union, and parts of Africa in the late 1980s and early 1990s of the last century. The issues of democracy, political pluralism, and human rights have become a reflection to a global trend. And becoming a democratic model of governance is a solution that characterizes with legitimacy at the global level. Hence, the third world countries were keen to appear to be in consistent with the line of this global trend and not standing outside it, especially with the growing interest of the United Nations, international financial organizations, and some Western countries in this issue, as well as defining what is known as the global civil society represented by international organizations, assemblies, and international bodies that deal with human issues, public freedoms, and other global issues.

The international community has expressed its belief in pluralistic democracy under the new international situation. On several occasions, in a speech to the UN General Assembly on October 1, 1990, it was said "Free elections are the basis of democratic governments and we can achieve dramatic successes like what we saw in Namibia and Nicaragua". Accordingly, the emphasis on the importance of democracy from the United States of America is at the core of the American strategy. The National Security Strategy of 2002 reaffirmed the importance of democracy to the goals of US foreign policy. The US National Security Strategy should look outside for possible expansion of freedom.

The European vision of the new system can be learnt through the decisions of the Paris Conference on Security and European Cooperation held in November 1990, which is one of the most important documents of the new international system. This conference emphasized democracy and multi-partyism, elections, and 
respect for human rights. The international community on January 31, 1992 was to emphasize the importance of democracy, human rights, and economic freedom. The West believes in the values of democracy and human rights as universal and fundamental values adopted by the international community through international charters and conventions, and therefore they should be sought by all nations and countries of the world.

In the face of this case, the third world countries found themselves forced to follow democratic regimes and pluralism for fear of being accused of anti-democracy by the West. Fearing that this issue would be used as a means and a weapon to interfere in its internal affairs was the inability of a certain group of countries to produce a genuine response from within, while refusing to adapt to international transformations.

This community is subjected to a process of continuous marginalization that ends with the imposition of almost total isolation and becomes, then, outside the present world time. It is ironic that the United States of America is advancing through the new international order to talk about the need for democratization by the developing countries after these countries were not qualified for that task, because of state of backwardness in order to be eligible for democracy. Obviously, these countries have been more backward than they were, meaning the continued lack of democracy for these countries as it was in past.

When the United States appears to make democracy one of the foundations of the new international order and try to impose it on countries without paying attention to their internal situation, it confirms that it is not an economic and social structure characterized by developing countries which control the presence or the absence of democracy, but is actually another case that is in the interest of the United States attempting to link and integrate the third world countries into the global market. This economic integration must be accompanied by political integration. As the world political system is democratic, this economic integration must be followed by political integration, thus the political order was characterized by democracy; thus, this integration is pushing the developing countries to submit themselves to the democratic system.

\section{The Role of the United Nations}

The collapse of the bipolar system and the end of the Cold War has created new formulas for the role of the United Nations. They have turned to the affairs that were at the heart of the internal jurisdiction of the states, such as the introduction of a new concept of sovereignty and intervention for humanitarian purposes and the protection of human rights on the basis that they are issues that affect international peace and security and they are not merely internal issues.

The United Nations, in its conferences and resolutions and in the words of its Secretary-General, has affirmed that democracy in this age is one of the main objectives of the Commission as the United Nations began calling on states to adopt democratic systems, because democracy within countries is the path to development, and it does not strengthen the spirit of innovation and freedom of communication and social stability, which has become necessary for economic and social successes in the information age. The importance of democracy stands out not as a goal, but as an approach, a process, as well as a procedural system that provides participation in the human societies of all citizens thus democracy among nations is considered the most clear and guaranteed basis for international cooperation and peace-building, as countries characterized with democratic systems absolutely do not fight each other.

Democracy has long been a cornerstone of the work of the United Nations, and the organization is supported through various means, such as the United Nations friendship missions to provide democratic alternatives to conflicts, peace-keeping efforts, assistance provided by the international organization to ensure 
the safety of the electoral process in some countries, which is used as a tool to defend democratic achievements. The United Nations also pledged to support the democratic transition in the world.

Despite this role played by the United Nations in promoting the spread of pluralistic democracy, it is determined by what the United States sees as that "the role of the international organization today is its subordination to the influence of the United States, diminishes the independence of the international organization and deprives the third world of opportunities as long as it enjoyed during the sixties and seventies of the last century to express options and attitudes".

\section{Information and Communication Revolution}

The continuation of scientific and technological progress has boosted the role of the external factor with added strengths in two aspects. The first is to facilitate the penetration of the third world countries and the effectiveness of its multifaceted influence through modern and advanced technologies used in communications. The effects of scientific and technological progress on the third world countries and the rapid progress of the industrial revolution have increased the changes existing within the third world countries and strengthened the mechanisms of penetration and challenges of the countries of the Western world.

Some researchers believe that this revolution participates in the consolidation of the process of democratic development and the trend towards pluralism in the third world countries based on the following reasons:

(1) It ends the monopoly of the ruling authorities of information, which is considered one of the pillars of the exercise of authoritarianism, the ability of these systems to control the freedom of opinion and expression and control of information sources, eroded rapidly as the information and communication revolution;

(2) The information and communication revolution contributes to raising the aspirations of citizens and creating new aspirations for them, as it conveys images of better political, economic, and social conditions, not only in the North world, but also in countries of the South;

(3) This revolution is representing a support to the forces and organizations of civil society and political opposition, as these organizations can communicate with the outside world easily and get away from state control, and can mobilize some international support for some legitimate demands, as well as the mobilization of international pressure on any gross violation of rights. In other words, this information and communication revolution has made the ability of regimes to conceal authoritarian practices very difficult, or an impossible proposal;

(4) The information and communication revolution allows for the dissemination of cross-border democratic values, ideas, and practices, which some people call the influence of infection. This influence is increasing in light of the global wave of democratization;

(5) The opposition forces in the third world countries have benefited from the tools of the information revolution, especially the Internet and fax machines, in exercising through their opposition against the ruling regimes.

Despite the importance of the information and communications revolution in influencing on the political development of the third world, this effect is affected by several factor represented by high illiteracy; the use of satellite is limited to few social groups in many third world countries, especially those which are characterized by an increase in population and high poverty rates.

Since the benefit of the information and communication revolution over the Internet requires knowledge of English language and computer, as well as the availability of financial ability to buy a computer and pay for 
access to the service of Internet, the use of the Internet is still an elite choice used in most of the third world countries.

\section{Conclusions}

The negative role of external factors can be emphasized through the US role that emphasized democratization. At a time when the United States supports dictatorial regimes in different parts of the third world, we note here that the standard is the interest of the United States; this system or that without relying on the criterion of good governance or democracy weakened the United States through dictatorships in the organizational capacity in many societies. While the interests of the United States today require regimes with a measure of stability and the ability to prevent radical change that brings the third world countries out of the scope of dependence, the United States saw an opportunity in the early 1980s to introduce some restricted democracy, which strengthens its systems without changing the radical changes in economic and political trends because of the systems.

This means that if the process of democratization is not a natural product of the development of society, its effects will be different. The third world may enter a severe crisis of legitimacy against the backdrop of democratic transformation due to tribal and ethnic conflicts and the rise of social strata calling for their participation in government.

\section{References}

Al-Aswad, S. (1973). Political sociology. Baghdad: Al-Arshaad Press.

Al-Fahad, A. R. M. (1985). African national liberation movement. Mosul: University of Mosul Press.

Al-Kadhim, S. J., \& Al-Ani, A. G. (1991). Political systems. Baghdad: Dar Al-Hikma Press.

Al-Shahawi, A. (1992). Crisis of the Zaire's government. Journal of International Politics, no. 107, January 1992.

Al-Taan, A. R. (1992). American democracy in Arab world under the new international order. Arab Journal of Political Science, no. 7, November 1992.

Alwan, H. (1994). The problem of political pluralism in third world. Journal of Political Science, University of Baghdad, no. 12, July 1994.

Arab Strategic Report 1995. (1996). Center of Political and Strategic Studies, Cairo.

Crusier, M. (1987). The contemporary testament (2nd ed.). (Y. A. Dagher \& F. M. Dagger, Trans.). Beirut: Owedan Publications.

Hadi, R. A. (1989). Political problems in third world (2nd ed.). Baghdad: Higher Education Press.

Hadi, R. A. (1995). Third world from one party to multiparty. Baghdad: House of Public Cultural Affairs.

Hadi, R. A. (1997). The third world: Issues and challenges. Baghdad: Dar Al-Sha'uun Al-Thakafia "Cultural Issues House".

Hadi, R. A. (1997). Third world from one-party to pluralism. Baghdad: House of Public Cultural Affairs.

Hammadi, S. (1975). Political parties and party systems (2nd ed.). Baghdad: Al-Arshaad Press.

Hassan, H. A. R. (2005). The experiments of democratic transformation in Africa. Journal of International Politics, no. 113, July.

Ibrahim, H. T. (2005). Arab political systems—Recent trends in its study (1st ed.). Beirut: Center of Arab Unity Studies.

Jawadl-Kadhim, S., \& Al-Ani, A. G. (1991). Political systems. Baghdad: Dar Al-Hikma Press.

Kochler, H. (1996). Democracy and the new world order. (S. Ibrahim, Trans.). Journal of Strategic Studies, Center of International Studies, University of Baghdad.

Majid, H. A. (1995). Determinants of relationship and crisis between systems and Islamic movement. International Issues Magazine, no. 283.

Metwally, M. (1981). Africa and western control. Cairo: Modern Knowledge “Al-Maarsf” Library.

Mohamed, A. H. (1982). Important stances in African history (1st ed.). Riyadh: Dar Al-Refai'ee Publishing, Printing and Distribution.

Panikar, M. (1962). African revolution, Khairi Hammad. Beirut: Dar Al-Tali'ieea'a Publications.

Ra'afatm, J. M. (1990). Somali Revolutionary Socialist Party and the perestroika. Journal of International Politics, no. 100, April 1990. 
Saadawi, A. A.-K. (1999). Political pluralism in third world. International Politics Magazine, no. 138, October 1999. Sabri, S. (1960). Africa beyond the desert, Egyptian renaissance. Cairo: "Al-Nahdha” Library.

Saleem, R. I. (1992). The new world order and its reflections for Africa. International Policy Magazine, no. 107, January 1992.

Shehata, S. M. (1995). Experiences of democratic movements in Africa and Arab world. Journal of International Politics, no. 121, July 1995. 